\title{
Student Directory
}

In an effort to better serve and assist the student members of the CIF/IFC, we have decided to create a student directory. Students of all university and technical programs across Canada can have their names, where they can be contacted, employment experience and desires listed in this directory. Potential employers will then have a readily accessible list of potential employees.

All universities and technical schools were notified of this service but the uptake has been slow. We will try to do a better job of promotion for next year's listing.

This service is available free of charge to all CIF/IFC student members; non-members are charged $\$ 25.00$.

The directory will be published annually in February.

BLACHFORD, Catherine, L. 868 Purcell Cresc., Kingston, Ontario K7P 1B9 (613) 384-6352, B.S.F., UBC, M.Sc.F. Lakehead University (In Progress). Research experience includes: forest and stand level ecology, boreal forest management strategies for spatial and temporal analyses of old-growth forest conservation, forest-inventory simulation modelling, geographic information systems, forestry/science - communications relationships. Teaching assistant for plant biology and forest policy; assistant to Ontario Advanced Forestry Program (OAFP). Work experience includes plantation, free-to-grow, site prep and survival assessments, harvest block layout and reserve marking (Ontario); juvenile spacing, and brushing and weeding projects, assistance with preharvest silvicultural prescriptions, and road layout/design (B.C.) Interested in forest management and planning, natural resource communications programs. Full CV available upon request. Willing to relocate. Available April 1993.

JOHNSON, Peter, J. 60 Inverness Avenue West, Hamilton, Ontario, L9C 1A4. Telephone: 416-383-1231. B.Sc.F. University of Toronto, M.Sc.F. Lakehead University. Thesis topic: "The Effectiveness of Dispute Resolution Mechanisms in Forest Resource Management in Ontario." Related research areas: conflict resolution through mediation and/or facilitation; effective public participation and alternate dispute resolution. Additional research areas include: independent forestry consulting in Canada and the United States; mediation in federal and provincial environmental assessment; forest policy analysis and international resource conservation. Work experience in sales and marketing of forest products, work exchange student to Finland, forestry teaching assistant, soil surveyor. Full CV available upon request. Willing to relocate. Available April 1993.

CHRISTIANSON, Marcy. \#103 1053084 Ave, Edmonton, AB, T6E 2H4, phone: (403) 432-0305. Will obtain Bsc in Forestry from University of Alberta, April
1993. 2 summers experience as a research assistant for Forestry Canada. Work experience includes plot location and establishment, mensuration, soil surveying and lab analysis. Desire to gain experience in all areas of forestry, especially silviculture. Will locate anywhere in Canada.

RITCHIE, Robert. C.P. 1032, St-Jacques, N.-B., E0L 1K0. Tél: (506) 258-3511. B.Sc.F de l'Université de Moncton, École de sciences forestières. Expérience en foresterie: deux étés en inventaire forestier, un été en aménagement de la faune, et un été en amélioration des arbres. Six ans d'expérience en pâtes et papiers. Recherche emploi en aménagement forestier, sylviculture, aménagement intégré des ressources et aménagement de la faune préférablement dans l'est du Canada mais prêt à voyager n'importe où. Disponible dès juin 1993 .

RITCHIE, Robert. P.O. Box 1032, St-Jacques, N.-B., E0L 1K0. Tel: (506) 258-3511. B.Sc.F from Université de Moncton, École de sciences forestières. Forestry experience: two summers in forest inventory; one summer in wildlife management; one summer in tree improvement. Six years experience in pulp and paper. Searching for employment in forest management, sylviculture, integrated resource management and wildlife management preferably in Eastern Canada but ready to travel anywhere. Available June 1993.

GODIN, Marc. 40 rue Queen, Edmundston, N.-B. E3V 1A1. Tel: (506) 735-8101. Université de Moncton (C.U.S.L.M.) 5th year in Forestry Science. Good public relation and report writing experience. Strong leadership sense and reliable. Seeking employment anywhere in Canada in the field of Forestry. Available for work from end of April, 1993.

PARSONS, Len. 1-545 Tweedsmuir Street, Fredericton, New Brunswick, E3B 4B9, (506) 451-8695. 3rd year B.Sc. For., University of New Brunswick. Forestry Canada (student technician) - experience in genetics and tree improvement of black spruce and willow. Domtar Forest Products (silvicultural supervisor) - experience in tree plants, aerial herbicide applications, regen surveys, mineral soil and duff assessments, mechanical site preparations and operations. Interested in a summer silviculture or operations position. Will locate anywhere in Canada. Available late April 1993. 